\title{
Notes on Experiments on the Early Developmental Stages of the Portuguese, American and English Native Oysters, with Special Reference to the Effect of Varying Salinity.
}

\author{
By \\ Ikusaku Amemiya. \\ Assistant Professor of Fisheries, Imperial University of Tokyo.
}

With 1 Figure in the Text.

CONTENTS.

1. Introduction

2. Culture-media . . . . . . 162

3. American oyster

a. Observations on development in waters of different salinities $\quad . \quad 162$

b. Some phenomena observed . . . . . . . . . . 167

4. Portuguese oyster . . . . . . . . . . . . . . 170

5. English native oyster . . . . . . . . . . . . . . . . 171

6. General consideration of salinity effects on the three species . . . . 173

Summary. . . . . . . . . . . . . . . 173

Literature . . . . . . . . . . . . . . . . . 174

\section{INTRODUCTION.}

WhILE staying at the Marine Biological Laboratory, Plymouth, in the summer of 1925 , I spent my time chiefly in the study of oysters, of which the following three species were available, the American, Ostrea virginica : the Portuguese, O. (Gryphca ) angulata: and the English native oyster, O. edulis. These three species are cultured in this country, although the first two were originally introduced from other countries.

It is well known that there is an intimate relation between the development and growth of the oyster and the salinity of the surrounding medium, the sea-water.

The chief purpose of this study was to determine to what extent the early developmental stages of the oyster are affected by the various concentrations of salinity of the sea-water, in what range of salinity its development is possible, and whether the range of salinity differs for the different species of the oysters, and if so, to find the optimum salinity for each species. 
I am greatly indebted to Dr. E. J. Allen, the director of the Marine Biological Laboratory, Plymouth, who afforded me every facility for my study, and to Dr. J. H. Orton for his valuable suggestions and the trouble he took to enable me to obtain the material. I wish to acknowledge also my thanks to Mr. H. W. Harvey, the hydrographer of the Laboratory, for his kind help in determining the salinity of culture-media.

\section{Culture-media.}

In the present study, observations were made on the metamorphosis of the larvæ in the course of their development. Culture-media of different grades of salinity were prepared, using sea-water collected a few miles from Plymouth in the English Channel. Media of higher salinity were obtained by evaporating this water in the air. Those having lower salinity were prepared by the addition of distilled water. Thus, culture-media of different grades of salinity, from a very low to an exceedingly high one, were obtained.

Two series of culture-media were always prepared. In the one series the media (200 c.c.) were kept in glass finger bowls with glass covers. In the other series, which acted as a control, the same volumes of media were kept in honey jars, the lids of which were tightly screwed down, so as to avoid evaporation, leaving enough space in the jars for the air. The salinities of the media were determined by titration and checked against " normal water" sent from Copenhagen.

\section{American Oyster (Ostrea virginica).}

\section{(a) Observations on development in waters of different salinities.}

This oyster has been introduced from America, and is now cultured in some parts of England. The material for the present study was sent from the Orford Oysterage of the Mac Fisheries Ltd., Orford, Suffolk, to whom I express my thanks.

The sexes in this species are normally separate and a hermaphrodite condition has only once been recorded in a single specimen by Kellogg (11). The ova when just spawned or squeezed out of the ovary artificially are not spherical, but rather irregular in shape, having a peculiar form resembling a flask or a pear; with a round body and a long tapering process. They have no gelatinous covering as often occurs in other bivalve mollusks. The surface of the ovum soon after it is shed into the water does not appear smooth, having many polygonal facets and ridges which, probably, are caused by the mutual pressure of the ova in the ovary, where they are packed closely together. However, after a little while in the water, the ovum changes its form and becomes spherical. The diameter of the egg when it has become spherical measures from $0.045 \mathrm{~mm}$. 
to $0.054 \mathrm{~mm}$. The nucleus is comparatively large and very clear, but soon after fertilisation has taken place, it disappears, so that it is easy to discern which eggs have been fertilised.

The present experiment was carried out late in July, i.e. in the spawning season of the species in this country.

Artificial fertilisation was very successful; almost 100 per cent of the eggs developed, provided the culture medium was favourable.

The following table shows the periods of time after insemination necessary for attaining the respective developmental stages. The temperature during the experiment fluctuated from $18^{\circ} \mathrm{C}$. to $21.5 \mathrm{C}$. As there is variation according to individuals, the average time is given in all cases.

\section{TABLE I.}

Appearance of 1st polar body . . . 40-50 min.

, , 2nd , , . . . 45-60 min.

1st segmentation . . . . 1 hour $15 \mathrm{~min} .-1$ hour $30 \mathrm{~min}$.

2nd . . . . . 1 hour 20 min. -2 hours.

Blastula, at the beginning of rotating movement, about . . . 6 hours $30 \mathrm{~min}$.

Beginning of invagination; the larva swims about . . . 8 hours.

Trochophore larva, about . . . 24 hours.

Larval shell grows large to cover the body except prototroch, about . 52 hours.

Larval shell measures $67 \times 78 \mu$, the larva begins to feed, about . . 60 hours.

In other concentrations of salinity which are unfavourable, development does not proceed so well, and retardation and other abnormal phenomena inevitably occur.

The following twenty-four culture-media which have varying grades of salinity were prepared for the rearing of embryos and the observation of effects of the different concentrations upon their development.

\begin{tabular}{lccccc} 
& Salinity $\%$ & & \multicolumn{2}{c}{ Salinity $\%$ Salinity $\%$ \%o } \\
No. 1 & $52 \cdot 1$ & No. 9 & $38 \cdot 5$ & No. 17 & $24 \cdot 5$ \\
No. 2 & $50 \cdot 4$ & No. 10 & $36 \cdot 8$ & No. 18 & $22 \cdot 8$ \\
No. 3 & $48 \cdot 7$ & No. 11 & $35 \cdot 1$ & No. 19 & $21 \cdot 0$ \\
No. 4 & $47 \cdot 0$ & No. 12 & $33 \cdot 3$ & No. 20 & $19 \cdot 3$ \\
No. 5 & $45 \cdot 3$ & No. 13 & $31 \cdot 6$ & No. 21 & $17 \cdot 5$ \\
No. 6 & $43 \cdot 6$ & No. 14 & $29 \cdot 8$ & No. 22 & $15 \cdot 8$ \\
No. 7 & $41 \cdot 9$ & No. 15 & $28 \cdot 0$ & No. 23 & $14 \cdot 0$ \\
No. 8 & $40 \cdot 1$ & No. 16 & $26 \cdot 3$ & No. 24 & $12 \cdot 3$
\end{tabular}

\section{TABle II.}


Ripe eggs and sperm were taken from female and male parents respectively. They were mixed, inseminated by the dry method, and then about $0 \cdot 25$ c.c. of the mixture was transferred to each culture medium.

To examine the course of the development in the media, the embryos or larvæ were picked up from each receptacle by a small pipette, dropped in rows on to one slide and studied simultaneously under the microscope.

The following description gives a rough outline of the course of development in the various concentrations :-

No. 1. Soon after having been transferred into the medium, the eggs shrink greatly and become irregular in their outline. At the end of 24 hours, very few eggs exhibit segmentation, which if it occurs is always abnormal. The greater part of the eggs remain unchanged, and show no sign of development. All degenerate in 3 days.

No. 2. Only very few eggs give off polar bodies at the end of 5 hours or more, or segment a few times at the end of 8 hours. Embryos are all abnormal, and no further progress of the development is seen. All degenerate before the morula stage.

No. 3. As in No. 2.

No. 4. The majority of eggs remain undeveloped, while some give off polar bodies in 3 hours or more and form embryos, almost all of which are abnormal. A very few produce at the end of 28 hours ciliated embryos which are unhealthy and very abnormal in structure, yet exhibit a rotating movement at the bottom of the receptacle. They all degenerate in 3 days.

No. 5. Some of the eggs remain undeveloped. A number develop to form embryos and larvæ. Their progress in development is very uneven; at 20 hours after insemination, some are in the first or second segmentation stage, some in the morulæ, others in the ciliated rotating larval stage; after 28 hours some become swimming larvæ. All of them are abnormal, and none can attain further stages of development.

No. 6. The greater part of the eggs begin to develop, but their segmentation is abnormal and the progress of development uneven. A few of them become trochophores at the end of 48 hours, but no further stages are obserred.

No. 7. Almost all the eggs begin to develop, but their segmentation is abnormal and the developmental process irregular and uneven. Those which attain the swimming trochophore stage with a small anlage of the laval-shell are fairly numerous, but none become good shell-larvæ. 
No. 8. Segmentation and the subsequent course of development are abnormal and uneven. Many eggs attain the swimming larvæ and trochophore stage, but hardly any become good shell-larvæ.

No. 9. Only a small number of the embryos can produce good, healthy shell-larvæ.

No. 10. The progress of development is uneven, and many abnormal forms are to be seen. Some produce healthy shell-larvæ.

No. 11. All eggs develop well, but some abnormal embryos and larvæ are observed. The progress of development is rather uneven.

No. 12. Fairly many produce good shell-larvæ.

No. 13. The progress of development is quite even. Almost no abnormal forms are met with. Very many produce good shelllarvæ.

No. 14. The progress of development is very even. No abnormal forms of embryos or larvæ are observed. All are very active, and produce the shell-larvæ at the end of 2 days.

No. 15. As in No. 14 .

No. 16. As in No. 15 .

No. 17. As in No. 16.

No. 18. Almost the same as in No. 17, but the progress of development is a little retarded.

No. 19. As in No. 18.

No. 20. A small number of eggs remain undeveloped. The progress of development is uneven and fairly retarded. The blastomeres are swollen. Many shell-larvæ are produced at the end of 4 days.

No. 21. Many eggs remain undeveloped. Abnormal embryos are numerous. The development is much retarded. Many swimming larvæ, but only a few shell-larvæ are produced.

No. 22. Blastomeres are very much swollen, and have a tendency to separate from each other. Non-segmenting eggs are numerous. The progress of development is very uneven and retarded. Many abnormal forms are observed. Fairly many swimming larvæ, fewer trochophores, and almost no shelllarvæ are produced.

No. 23. A number of the eggs remain undeveloped. Many exhibit abnormal segmentation. Some produce abnormal and unhealthy swimming larvæ, but no shell-larvæ.

No. 24. Abnormal segmentation occurs in a number of eggs. All degenerate before attaining the ciliated embryo stage. 
The preceding description shows roughly how the development of the oyster embryos is affected by the various grades of salinity.

From this result it can be seen that in high salinity, such as No. 1-No. 3, the eggs are much plasmolysed and a large proportion show no sign of development, remaining unsegmented. Although a few form polar bodies and reach the early segmentation stage, this process is very slow, they are all abnormal and the arrangement of the blastomeres is irregular. They all degenerate and disintegrate sooner or later before attaining the ciliated stage.

In No. 4-No. 8, there are some non-segmenting eggs; others are developing ones, and their number as well as the stage which they can attain are both variable and depend on the grade of salinity; the number increases and the stage reached progresses further with the decrease of salinity. However, the development never reaches the stage of shelllarvæ. Moreover, it is noticeable that in high salinity as in No. 1-No. 8, the progress of development is uneven, and segmentation and growth are abnormal.

In No. 9 -No. 12, the conditions become more favourable, and this is even more marked in No. 13. Normal healthy shell-larvæ are obtained in these cases, and they increase much in number in No. 13, although more or less abnormal forms are still present.

In No. 14-No. 17, the conditions are most favourable ; all eggs develop, the process of development is very even, and very short, the larvæ are very active, and almost all develop up to the shell-larvæ and further stages.

In No. 18-No. 19, the conditions are not so favourable as in the previous Nos. ; there are some non-segmenting eggs. The progress of development is a little retarded, and some embryos develop abnormally.

In No. 20 and No. 21, eggs become swollen soon after being placed in the media. There are non-segmenting eggs, the number of which increases very much in No. 21. Many embryos with an irregular and abnormal arrangement of blastomeres are produced. The progress of development is uneven, much so in No. 21. There is an abrupt decrease in the number of the normal shell-larvæ in No. 21 compared with No. 20.

In No. 22 and No. 23, eggs become much swollen and non-segmenting eggs are many. Abnormal forms are also numerous. The developmental process is very uneven; at the end of three days, all the stages of development are represented, i.e. segmentation, morula, blastula, young swimming larva, trochophore, and a few shell-larvæ.

In No. 24, a number of eggs remain undeveloped. Others segment only abnormally and very slowly, but none can attain the ciliated moving or swimming larval stages. All degenerate and disintegrate in two days. 


\section{(b) Some phenomena observed.}

I wish now to discuss some particular phenomena in the developmental process caused by unfavourable salinity of the medium, although several points regarding the phenomena have already been mentioned above.

Retardation of development owing to unfavourable salinity conditions ; It is a well-known fact that the rate of development of any animal is influenced by temperature. Stafford (16) and others have already observed its influence on the development of the oyster.

However, as far as I am aware, the effect of salinity on the rate of development of the oyster or any other animal has not yet been well studied. As shown above, oyster eggs used in the experiments which were fertilised at the same time and cultured under the same conditions, except in regard to salinity, took different periods of time for their development; a short time in a moderate concentration, and longer when the concentration was too high or too low. Thus, the retardation increases in both directions, in the higher and the lower concentrations of salinity.

This fact is one of the characteristic marks for determining the favourable salinity of a medium for the development of the oyster.

Abnormal forms due to the too high and the too low concentrations of the salinity; $\mathrm{O}$. and R. Hertwig (10) observed in the frog egg abnormal early development in plasmolysed condition in salt water; in certain circumstances segmentation took place in the form of "Knospenfurchung." Loeb (12) showed that in high concentration (addition of $\mathrm{NaCl}$ to the natural sea-water) of the medium cleavage of Arbacia eggs was irregular and abnormal. Herbst (6, 7, and 8) also observed that the blastomeres of Echinus in its early development have a great tendency to lie apart or become isolated from each other in Ca-free or other artificial sea-water.

In the case of the oyster, I also observed a phenomenon similar to those noted by previous authors, although the media which I used were different; their component salts and their mutual ratios are unaltered as compared with the natural sea-water, only the concentration as a whole is altered. The process of cleavage of the oyster embryos has some difference embryologically from that of either the sea-urchin or the frog, but they are all similar in that their early development is by total segmentation.

In the oyster, in too high as well as in too low concentration of salinity, many individuals showing abnormal segmentation occur which they exhibit in some peculiar features. For example, some very small blastomeres are often formed abnormally resembling budding of fungus plants, as " Knospenfurchung," described by O. and R. Hertwig (10) in the case of the egg of the frog. The arrangement of blastomeres of such abnormal oyster embryos is therefore somewhat reminiscent of a colony 
of yeast. Such a deformed larva cannot remain alive long and dies sooner or later.

Moreover, in too high and too low salinity, the blastomeres which are formed by segmentation have a great tendency to lie apart from each other, while in normal development they lie closely attached and applied to one another. In some cases, some of the blastomeres often separate from their fellows, and in this state they undergo further development, so that they cannot become normal larvæ. Accordingly, this leads to abnormality or monstrosity of the embryos and larvæ.

Such abnormal forms continue their further development to some extent, especially in the too high concentration, and can often attain a swimming stage, developing cilia on the body surface.

As regards the development of isolated blastomeres of the embryo, there exists evidence relating to other animals. Amongst those, the results of studies on echinoderm eggs by Driesch (6), Loeb (12), and Morgan (13) are most useful for reference. They succeeded in producing small, complete larvæ, "partial larvæ" of Morgan. Their methods of obtaining the isolated blastomeres were not always the same. Driesch used the application of Ca-free artificial sea-water, the other workers mechanical ways, but their results agree fairly well with each other in that they succeeded in producing complete dwarf larvæ of sea-urchins (Arbacia, Echinus, and Sphrorechinus).

Although the primary aim of this study was not the investigation of "partial larvæ" in the case of the oyster, it was observed that they did occur not infrequently in the natural sea-water whose salinity is very high.

The isolated blastomere or blastomeres can attain a trochophore or more advanced stage of larva whose size is naturally much smaller than normal, yet it is very active and swims very well in the medium. However, I cannot help doubting whether such dwarf larva can develop further to produce healthy normal spat.

The production of abnormal forms of oyster larvæ in too high as well as too low salinity is, in my opinion, entirely due to the exceedingly high or low osmotic pressure of the medium.

The appearance of abnormal forms in the medium is also a good indication as to whether the concentration of the medium is moderate or not.

Non-segmenting eggs due to unfavourable salinity; In higher and lower concentrations of salinity more frequently than in a moderate one, there are eggs which do not undergo segmentation and remain long undeveloped, eventually dying. They are impregnated eggs, and it would appear that the fertilisation is well performed as their nuclei disappear. Some of them give off the first polar body or also the second, but then cease to develop further. Such non-segmenting eggs are met with both in the higher 
and in the lower salinity, but not in the moderate one. Their number increases divergently from the moderate salinity towards the higher on the one hand and the lower on the other.

It is thus obvious that their occurrence is the direct result of an unfavourable effect of the unsuitable salinity.

Consideration of the effect of salinity conditions on the development; As described above, the early development of the oyster is affected by the grades of salinity whose influence is manifested in many ways, namely, the rate of development, irregularity of development in unsuitable conditions, the occurrence of non-segmenting eggs, of abnormal forms, and of plasmolysed and plasmoptysed states of the embryos. These facts are good indications of the effect of salinity conditions on the development of oyster larvæ. For the American oyster they may be summarised in the following table :-

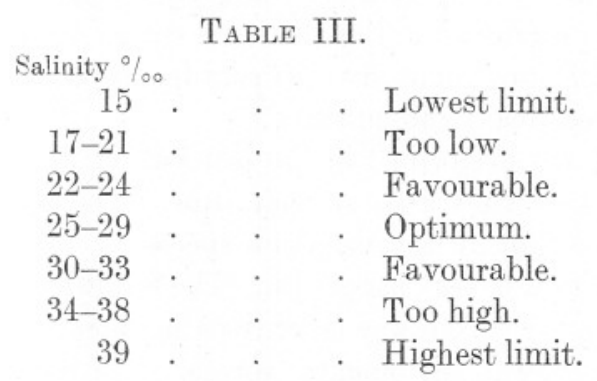

Feeding experiments on young shell-larva; I wish to add here some notes on the feeding of larvæ which begin to take food at least two days after fertilisation.

Previous investigators as, for instance, Stafford (16), have noticed that the larvæ which have developed to the stage of young shell-larvæ are very difficult to keep alive long and to grow in the culture-media; this was probably due to a lack of suitable food, which consists of very minute organisms.

Dr. E. J. Allen has several kinds of minute algæ in his laboratory kept in the condition of "persistent culture." He placed very kindly samples of his important cultures at my disposal for the feeding of oyster larvæ. At first, I used for the feeding a species of Nitschzia, a plankton alga, one of the smallest Diatoms, but this alga is still too large to be taken by the larvæ, and they cannot feed on it. Next, Pontosphara Huxleyi, a flagellate, $2 \cdot 5-3 \mu$ in size, was tried. The oyster larvæ feed on it well; the algæ taken are easily discernible in the stomachs of the larvæ whose bodies are quite transparent when young. They grow until their shells become $145 \times 130 \mu$ in diameter; the intestinal part of their digestive tract, which was at first short and quite simple, elongates much and becomes twisted to form a loop. The umbo of the shells swells up and 
protrudes in the form of a vault. The liver is tinged with a green pigment which makes this organ very conspicuous in the body which itself becomes gradually dark and opaque under the microscope.

The larvæ live in jars of sea-water containing this flagellate for as long as two weeks or more, but their growth is not so successful as to attain a larger size than that mentioned above, although there is no marked sign of other unhealthy conditions.

\section{Portuguese oyster $(O$. (Gryphaca) angulata).}

The sexes of the species are normally separate, as has been investigated and reported by M. Bouchon-Brandley (2), J. A. Ryder (15), and J. L. Dantan (3, 4, and 5). However, I. Amemiya (1) observed the occurrence of hermaphroditism of this species, when ripe eggs and sperm were found in the same individual and in the same tubule of the gonad.

Oysters used for the present study were sent from Whitstable Oysterage, where they had been relaid and cultured.

The experiment was performed in the last half of July. Their reproductive elements were fully ripe at that time. The size of the egg is exactly the same as that of the American species.

Artificial fertilisation is very successful. The following table shows the time which under most favourable conditions it takes after insemination to attain the respective developmental stages. The temperature during the experiment fluctuated from $20^{\circ} \mathrm{C}$. to $23^{\circ} 5 \mathrm{C}$.

\section{TABle IV.}

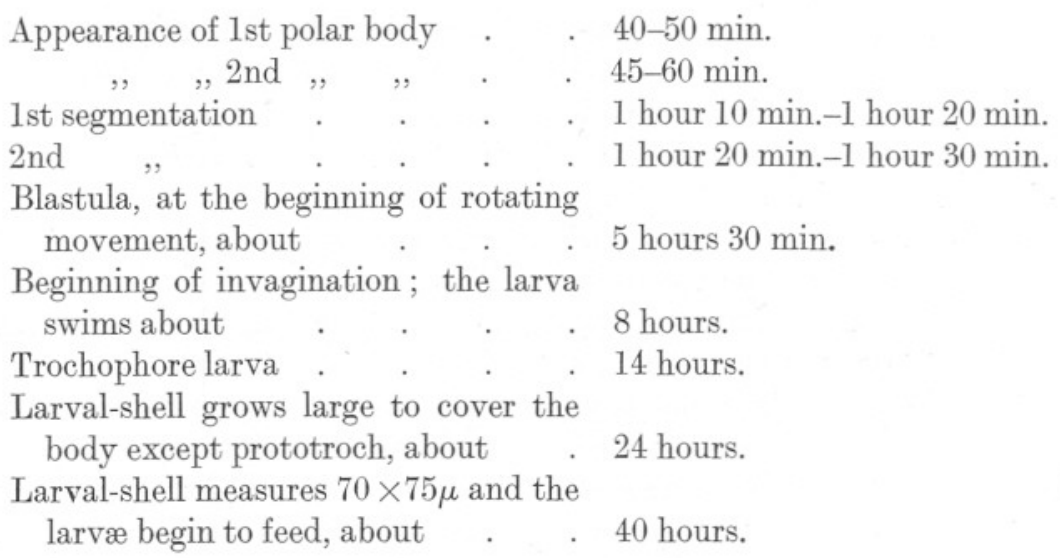

Thus, the progress of development is very speedy, as the temperature was fairly high. This table is the record of development in the medium with optimum salinity. 
To observe the conditions in the various grades of salinity, many media of graded concentration were prepared, and the development of fertilised eggs was studied just in the same way as in the American oyster. The course of development and the phenomena observed in the experiment are also similar, so that it would be unnecessary to describe them in detail for this species particularly.

From results I obtained, it may be concluded that the salinity conditions for the Portuguese oyster are as shown in the following table :-

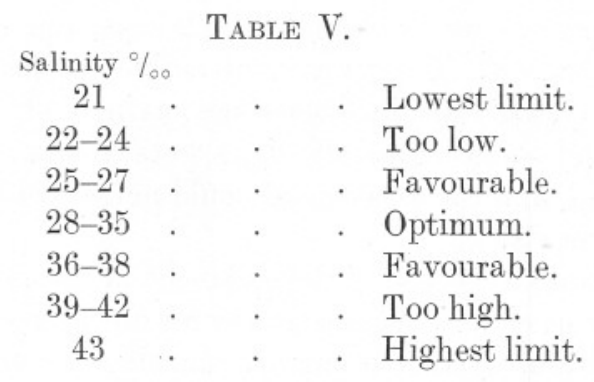

Shell-larvæ which have attained the size above mentioned by about 2 days, do not grow further, as they are in rather a starving condition owing to the lack of suitable food in the medium, yet they are very active and healthy and live for many days in the Laboratory.

\section{English Native Oyster (O.edulis).}

This species has long been known as hermaphrodite, and its sexual phenomena were studied very fully by Dr. J. H. Orton (14, $a$ and $b)$.

It has very large eggs, much larger than those of diœcious species, such as the American and the Portuguese oysters. The ovum measures on an average $0.10 \mathrm{~mm}$. in diameter.

The mode of fertilisation and early development are quite different from those of diœcious species, as fertilisation takes place in the parent's shell cavity, and the early part of the life of the offspring is normally spent there. The segmentation of the fertilised eggs and the general course of development are, however, morphologically the same.

Artificial fertilisation is not successful in this species, but it does not seem difficult to obtain embryos of the early developmental stage, as the parent oyster in the spawning season, if it is taken out of the water and left in the air, very often extrudes its very young spawn from the shell.

The material used for the present study was placed at my disposal by Dr. J. H. Orton, who was at that time engaged in another line of study on the oyster. 
By the time the material was obtained and the experiment started the embryos were already young morulæ, whose age could be computed as about 20 hours after fertilisation. They were put into the graded media, and their developmental conditions were observed in the same way as in the previous experiments. The time was late July, and the temperature during the experiment fluctuated from $16 \cdot 2^{\circ} \mathrm{C}$. to $18^{\circ} \mathrm{C}$.

The development of embryos in the media of moderate salinity was normal in that they reached the trochophore stage in 3 days and a half. Invagination began 7 hours after the embryos were put into the medium; ciliated, rotating larvæ were obtained after 2 days, and good trochophores after 3 days and a half. They were very active and healthy.

On the fifth day, a few attained the stage having shell-anlage, but many of them died and some unhealthy signs were observed. On the sixth day all were dead, and the experiment could not be continued to observe further developments.

Observations on the course of development in the graded media were made as in other species. Phenomena which were noticed in the American and the Portuguese oysters occurred, namely, the speedy process of development in moderate salinity, retardation in the unfavourable ones, the occurrence of abnormal embryos and larvæ, etc. But it is unfortunate that the experiment ceased before satisfactory results were obtained.

However, from the record which was obtained, the following result (Table VI) may be derived, which shows the relation between salinity and development of the English native oyster :-

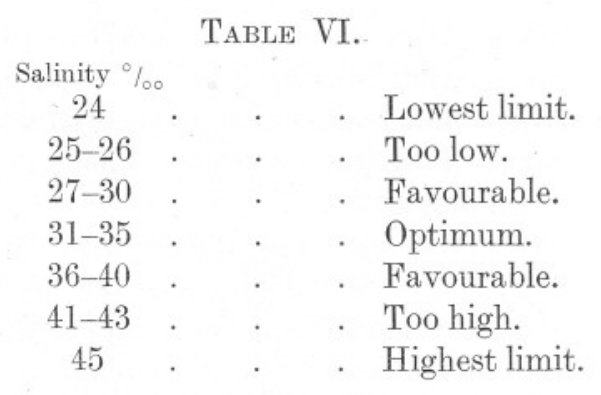

As stated already, observations were not made at the very beginning of the development of the fertilised eggs.

The rearing of young larvæ is not easy in this species, and to follow the metamorphic changes of larvæ in the culture medium in the laboratory is very difficult. Yet, in the present experiment, embryos lived for 5 days and exhibited reliable reactions to graded concentrations.

I am not inclined to regard the results obtained as sufficient to form conclusions on, but as far as they go they appear to be quite reliable. 


\section{General Consideration of Salinity Effects on the Three Species.}

As has been described, the three species of oyster here dealt with have each their own salinity ranges for early development.

Fig. 1 is a graphic representation which shows at a glance how these ranges compare with one another.

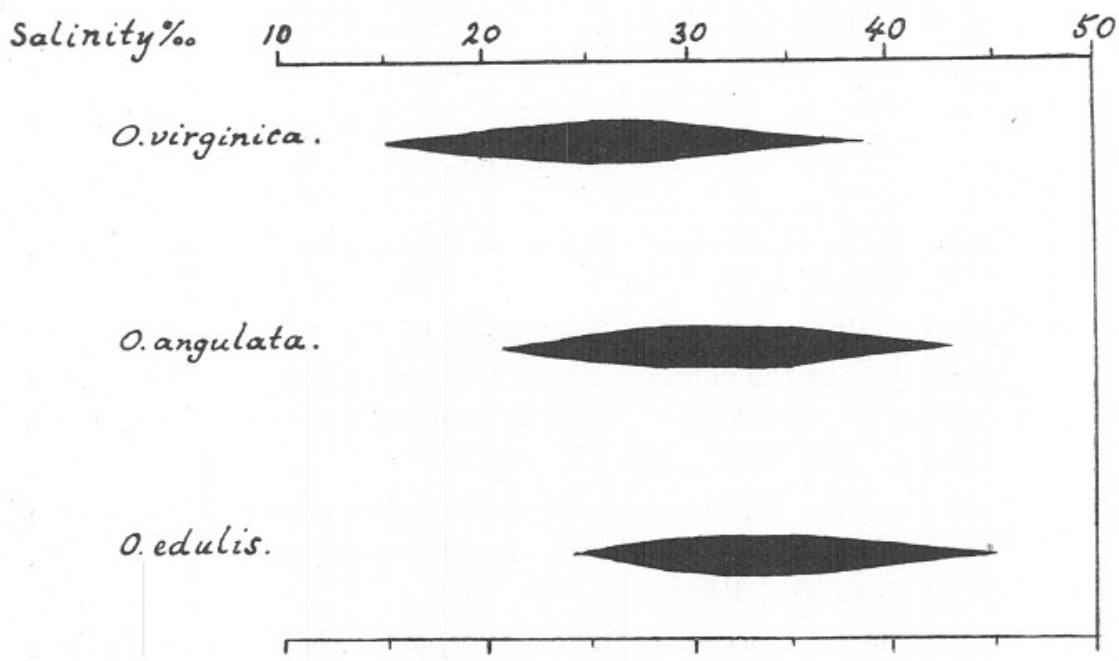

Text Fig. 1.-Diagram showing the Salinity ranges for the three species of oyster $O$. virginica, $O$. angulata and $O$. edulis. The thickest portion in each case represents the range of optimum sulinity.

It can be seen from the diagram that, with some characteristic variations, the three salinity ranges coincide in their main portions. The American oyster lies in the lowest, the Portuguese is intermediate, while the English native lies in the highest salinity range.

\section{SUMMARY.}

1. The period of time which the oyster larva requires to attain its respective developmental stages was measured and recorded in $O$. virginica and $O$. angulata.

2. The development in various concentrations of salinity was studied in the three species, O. virginica, O. angulata, and $O$. edulis.

3. In optimum salinity, all the impregnated eggs undergo segmentation and further development; the rate of development is uniform and its progress speedy. 
4. In the too high as well as in the too low salinity, "Knospenfurchung " and abnormal larvæ were observed. In the too high salinity, "partial larvæ" were not infrequently met with.

5. Ranges of salinity optimal and possible for the development of the three species were determined.

6. The larvæ of the American oyster which were raised by artificial fertilisation and fed with Pontosphora Huxleyi grew until their shells measured $130 \times 145 \mu$ in diameter.

\section{LITERATURE.}

1. Amemrya, I. Hermaphroditism of Portuguese Oyster. Nature, No. 2921, Vol. 116. 1925.

2. Bouchon-Brandley, M. Translated by J. A. Ryder. On the sexuality of the common oyster $(O . e d$.) and that of Portuguese oyster (O. angulata). Artificial fecundation of the Portuguese oyster. B.U.S.F.C., Vol. II. 1882.

3. Dantan, J. L. La fonctionment de la glande génitale chez l'Ostrea -edulis et le Gryphcea angulata. La protection des banc naturales. C.R. Acad. Sc., Paris. T. 155. 1912.

4. — - L'huitre portugaire (Gryphaea angulata. Lam.) tend-elle à se substituer a l'huitre (O. ed.) ? Ibid. T. 158. 1914.

5. _ _ L La biologie des huitre et l'industrie ostreicole. Bull. Inst. Oceanogr. Monaco., No. 341. 1918.

6. Driesch, H. Die isolierten Blastomeren des Echinodermenkeimes. Eine Nachpfrüfung und Erweiterung früherer Untersuchungen. Arch. f. Entw.-Mech. d. Org., Bd. X. 1900.

7. Herbst, C. Experimentelle Untersuchungen über den Einfluss des Mediums. II. Weiteres über die morphologische Wirkung der Lithiumsalze. Mitt. Zool. St. Neapel. 11. 1893.

8. — - Ueber Auseinandergehen von Furchungs- und Gewebezellen im Kalkfreien Medium. Arch. f. Entw.-Mech. d. Org., Bd. IX. 1900.

9. _ - Ueber die zur Entwicklung der Seeigellarven notwendigen anorganischen Stoffe, ihre Rolle und ihre Vertretbarkeit. III. Teil. Die Rolle der notwendigen anorganische Stoffe. Arch. f. Entw.-Mech. d. Org., Bd. XVII. 1904.

10. Hertwig, O. and R. Ueber den Befruchtungs- und Teilungsvorgang des tierischen Eies unter den Einfluss äusserer Agentien. Jen. Zeitschr., XX. 1887. 
11. KellogG, V. L. A contribution to our knowledge of the morphology of lamellibrancheate mollusks. B.U.S.F.C. for 1892.

12. Loeb, J. Investigations in Morphological Physiology. III. Experiments on cleavage. Journ. of Morph., Vol. VII. 1892.

13. Morgan, T. H. Studies on the "partial larvæ" of Sphærechinus. Arch. f. Entw.-Mech. d. Org., Bd. II. 1895.

14. ORton, J.H. (a) The phenomena and conditions of sex change in the oyster (O. edulis) and Crepidula. Nature, Vol. 110. Aug. 12th, 1922.

(b) Sex change and breeding in the Native Oyster (O. edulis). Nature, Vol. 114. Aug. 9th, 1924.

15. Ryder, J. A. The microscopic sexual characteristics of the American, Portuguese, and common edible oyster of Europe compared. B.U.S.F.C., 1882, Vol. II.

16. Stafford, J. The Canadian oyster. 1913. 
